\title{
Phytochemical Screening of Certain Medicinal Plants of Mizoram, India and their Folklore Use
}

Longjam Shantabi, Ganesh Chandra Jagetia*, Vabeiryureilai M and Lalrinzuali K

Department of Zoology, Mizoram University, Tanhril 796004, Aizawl, India

*Corresponding author: Ganesh Chandra Jagetia, Professor, Department of Zoology, Mizoram University, Tanhril 796004, Aizawl, India, Tel: 91-0389-2330514, 2330227; E-mail: gc.jagetia@gmail.com

Received date: Oct 06, 2014, Accepted date: Nov 06, 2014, Publication date: Nov 10, 2014

Copyright: @ 2014 Shantabi L, et al. This is an open-access article distributed under the terms of the Creative Commons Attribution License, which permits unrestricted use, distribution, and reproduction in any medium, provided the original author and source are credited.

\begin{abstract}
The inhabitants of Mizoram (Mizos) use several plants for their healthcare and our main interest was to investigate the scientific basis of the medicinal use of these plants. Therefore, the root-stock of Alocasia indica, mature leaves of certain plants including Biden pillosa, Blumeopsis flava, Chromolaena odorata, Cissus discolor, Croton caudatus, Elaeagnus caudata, Leucaena leucocephala, Passiflora edulis and Spilanthes acmella, the latex of Carica papaya and rhizomes of Curcuma caesia were dried and powdered. The chloroform, ethanolic and aqueous extracts of each plant was prepared and subjected to phytochemical analysis and thin layer chromatography (TLC). The phytochemical analysis of the above plants showed the presence of alkaloids, flavonoids, saponins, and steroids. Most of these plants contained tannins with the notable exception of Croton caudatus. Similarly, the majority of plant species analyzed showed the presence of phlobatannins except Spilanthes acmella and Passiflora edulis. The cardiac glycosides were absent in Elaeagnus caudata and terpenoids in Leucaena leucocephala and Elaeagnus caudata. The presence of different phytochemical constituents was confirmed by TLC profiling by comparing the $\mathrm{Rf}$ values in various solvent systems. Our study indicates that despite the lack of real knowledge of chemistry, the traditional healers knew the medicinal importance of these plants. The medicinal properties of these plants may be due to the presence of various phytochemicals including flavonoids, alkaloids, saponin, steroids, tannins, phlobatannins, terpenoids and cardiac glycosides.
\end{abstract}

Keywords: Ethno-medicinal plants; Phytochemical analysis; Traditional use; TLC profiling

\section{Introduction}

The use of plants for healthcare is as old as the human civilization. However, the earliest record of use of plants for treatment of various ailments can be found in the oldest Hindu scripture, the Rig Veda that dates back to 3500 B.C. to 1800 B.C. The elders of India did realize the importance of plants as medicines and documented the medical usage of several plants in several pious scriptures of Vedic times. Various other scriptures including Atharvaveda (1200 BC), Charak Samhita and Shusrut Samhita (1000-500 BC) have also given a threadbare account of medical application of more than 700 herbs [1]. The earliest known written medical prescription is about four thousand years old, where Sumerian clay tablets showed remedies for various illnesses [2]. Sumerian prescribed mandrake plant for pain relief, turmeric for blood clotting, endive plant roots for treatment of gall bladder disorders, and raw garlic for circulatory disorders. Despite the advent of modern medicine, the popularity of plant/natural products as treatment modalities for various ailments has increased worldwide due to their nontoxic or less toxic nature and the lesser known side effects than the modern generic drugs $[3,4]$.

The interest of public in the alternative and complementary medicinal systems of healthcare has been renewed, because the modern system of medicine failed to cure several chronic diseases, which make the patients invalid, whereas the Ayurveda and other alternative systems of medicine have been able to cure these diseases effectively $[4,5]$. Recently alternative and complementary medicinal systems of healthcare including Ayurveda have attracted the attention of many Western countries and they have been now recognized by the World Health organization as important treatment modalities for human healthcare. The alternative and complementary medicinal systems have been playing and continue to play a major role in the human healthcare sine they are cheap and economic and in easy reach of all strata of population including reach and poor. An estimate by WHO indicates that approximately $80 \%$ of the population mainly relies on their healthcare needs in the developing countries and even developed countries. Listing by WHO indicates that 20,000 medicinal plants are used for healthcare globally and out of this India is abode for $15-20 \%$ medicinal plants $[6,7]$.

The ethnomedicine is practiced for healthcare by several ethnic groups inhabiting the globe and India abounds in the indigenous traditional knowledge of medicinal plants since ancient times. This traditional knowledge of healthcare has been transmitted from one generation to the next generation for thousands of years. However, due to the advent of modern medicine there has been a declining trend in the traditional, alternative and complementary medicinal systems and ethno-medical practices, which indicates the need for rejuvenation of these systems especially by proper documentation and investigation of the science behind these practices in the modern context [8].

Plants synthesize numerous complex phytochemicals for nutrition, defense against stress, to fight unwanted predators, and facilitate pollination. The different phytochemicals synthesized by plants are very useful for human healthcare since they have been reported to produce many beneficial effects on humans due to their medicinal properties [9]. This indicates that phytochemicals based approach on ethno-pharmacological information is one of the important paradigms for new drug development and combinatorial chemistry [10]. There is 
no denying the fact that $70 \%$ of the modern medicines had been derived from the plants/natural products or had their origin in them [11]. Therefore, it is pragmatic to screen plants for new drug development by studying their chemical constituents and also establish scientific basis of their traditional use. Mizoram is small state of India and is located in its Northeastern region. It is one of the 25 megabiodiversity hotspots of the world, where more than 400 species of medicinal plants are found. The local population of Mizoram ingeniously uses these plants for their healthcare needs [12]. Therefore, the present study was undertaken to obtain an insight into the phytoconstituents of certain plants and correlate the scientific basis of their medicinal use by the traditional healers of Mizoram.

\section{Materials and Methods}

\section{Collection and identification of plants}

Alocasia indica (Roxb.) Schott, Bidens pillosa L, Blumeopsis flava (DC.) Gagnep., Carica papaya Linn., Chromolaena odorata (L.) R.M. King \& H. Rob., Cissus discolor Blume, Croton caudatus Geiseler, Elaeagnus caudata Schlecht. exMomiy, Leucaena leucocephala (Lam.) De Wit, Passiflora edulis Sims and Spilanthes acmella Murr. were collected from Aizawl and Champhai districts of Mizoram. All plants were identified by the elders of the Mizo community and authenticated by the Department of Horticulture Aromatic and Medicinal Plants, Mizoram University, Aizawl, India.

\section{Preparation of plant extracts}

The non-infected root-stock of Alocasia indica, mature leaves of Biden pillosa, Blumeopsis flava, Chromolaena odorata, Cissus discolor, Croton caudatus, Elaeagnus caudata, Leucaena leucocephala, Passiflora edulis and Spilanthes acmella, the latex of Carica papaya and rhizomes of Curcuma caesia were collected, air-dried in shade and grinded. The powders were individually extracted in cold by maceration in chloroform, ethanol and distilled water, respectively at room temperature for $48 \mathrm{~h}$. The individual extracts were filtered using a Whatmann filter paper No. $42(125 \mathrm{~mm})$ and concentrated using a rotary evaporator.

\section{Phytochemical screening}

The presence of various phytochemicals in root-stock of Alocasia indica, mature leaves of Biden pillosa, Blumeopsis flava, Chromolaena odorata, Cissus discolor, Croton caudatus, Elaeagnus caudata, Leucaena leucocephala, Passiflora edulis and Spilanthes acmella, the latex of Carica papaya and rhizomes of Curcuma caesia was detected using standard procedures described below.

\section{Test for alkaloids}

$0.5 \mathrm{~g}$ of extract was dissolved in $10 \mathrm{ml}$ of acidified alcohol, boiled and filtered and to $5 \mathrm{ml}$ of the filtrate, $2 \mathrm{ml}$ of dilute ammonia was added followed by the addition of $5 \mathrm{ml}$ of chloroform. The mixture was shaken gently to extract the alkaloidal base. The chloroform layer was further extracted with $10 \mathrm{ml}$ of acetic acid and divided into two parts. Mayer's reagent was added to one part, whereas Draggendorff's reagent to the other. The formation of a cream (Mayer's reagent) or reddish brown precipitate (Draggendorffs reagent) indicated the presence of alkaloids $[13,14]$.

\section{Test for tannins}

About $0.5 \mathrm{~g}$ of dried powdered samples was boiled in $20 \mathrm{ml}$ of water in a test tube and filtered. A few drops of $0.1 \%$ ferric chloride was added to the filtrate. The formation of brownish green or a blue-black colour indicated the presence of tannins $[13,14]$.

\section{Test for phlobatannins}

The aqueous extract of each plant was boiled with $1 \%$ aqueous hydrochloric acid and deposition of a red precipitate indicated the presence of phlobatannins $[13,14]$.

\section{Test for saponins}

Usually $2 \mathrm{~g}$ of each powdered sample was separately boiled with 20 $\mathrm{ml}$ of distilled water in a water bath for 10 minutes and filtered while hot and cooled before conducting the following tests:

Frothing: $3 \mathrm{ml}$ of filtrate was diluted up to $10 \mathrm{ml}$ with distilled water and shaken vigorously for 2 minutes. The formation of a fairly stable froth indicated the presence of saponins in the filtrate.

Emulsification: 3 drops of olive oil was added to the solution obtained by diluting $3 \mathrm{ml}$ filtrate to $10 \mathrm{ml}$ distilled water and shaken vigorously for a few minutes. The formation of a fairly stable emulsion indicated the presence of saponins [13-15].

\section{Test for flavonoids}

The presence of flavonoids was determined in all the extracts using three different methods $[13,14,16] .5 \mathrm{ml}$ of dilute ammonia solution was added to a portion of the aqueous filtrate of each plant extract followed by the addition of a concentrated $\mathrm{H} 2 \mathrm{SO} 4$. Appearance of a yellow colour (disappeared on standing) in each extract indicated the presence of flavonoids.

A few drops of $1 \%$ aluminum solution were added to a portion of each filtrate. A yellow colour indicated the presence of flavonoids.

A portion of the each plant powder was heated with $10 \mathrm{ml}$ of ethyl acetate over a steam bath for $3 \mathrm{~min}$. The mixture was filtered and $4 \mathrm{ml}$ of the filtrate was shaken with $1 \mathrm{ml}$ of dilute ammonia solution. A yellow colour indicated the presence of flavonoids.

\section{Test for steroids}

The presence of steroids was determined by adding $2 \mathrm{ml}$ of acetic anhydride into $0.5 \mathrm{~g}$ ethanolic extract of each sample followed by the addition of $2 \mathrm{ml}$ sulphuric acid. The change from violet to blue colour or green in some samples indicated the presence of steroids $[13,14]$.

\section{Test for terpenoids}

Four milligrams of plant extract were treated with $0.5 \mathrm{ml}$ of acetic anhydride and $0.5 \mathrm{ml}$ of chloroform, followed by the slow addition of concentrated solution of sulphuric acid. The development of red violet or blue colour indicated the presence of terpenoids.

Salkowski test: Five $\mathrm{ml}$ of each extract was mixed with $2 \mathrm{ml}$ chloroform, with a careful overlaying of $3 \mathrm{ml}$ concentrated sulphuric acid. The formation of a reddish brown precipitate at the interface indicated the presence of terpenoids $[13,14]$. 


\section{Test for cardiac glycosides (Keller-Killani test)}

Usually $5 \mathrm{ml}$ of each extract was treated with $2 \mathrm{ml}$ of glacial acetic acid containing one drop of ferric chloride solution with an under laying of $1 \mathrm{ml}$ of concentrated sulphuric acid. The appearance of brown ring at the interface indicated the presence of deoxysugar, which is characteristics of cardenolides $[13,14]$.

\section{TLC analysis}

TLC is an inexpensive, simple, and a rapid technique, which separates the number of components present in any non-volatile complex mixture or plant sample using a suitable solvent for separation of different components. The plant extracts were spotted in $1 \mathrm{~mm}$ diameter on the TLC plates (Merck India, Kolkata, India) using standard methodology and inserted into the mobile phase containing various compositions of different solvents. The extracts were allowed to move on the adsorbent (stationary) phase on the TLC plates. The mobile phase consisted of various combinations of solvents in order of increasing polarity including $\mathrm{n}$-hexane (n HX)/ethyl acetate(EtOAc) (7:3), benzene $\left(\mathrm{C}_{6} \mathrm{H}_{6}\right)$ /acetone $\left(\mathrm{Me}_{2} \mathrm{CO}(9.5: 0.5)\right.$, chloroform $\left(\mathrm{CHCl}_{3}\right)$ / methanol $(\mathrm{MeOH})$ (3:2), dichloromethane $(\mathrm{DCM}) / \mathrm{MeOH}(8: 2)$ and $\mathrm{DCM} / \mathrm{MeOH}(9: 1)$. The various combinations of mobile phase allowed the separation of different components of the plant extracts that had distinct RF values. The RF value is a measure of the distance a compound travels. In each case the TLC spots were visualized under day light or UV light.

\section{Results}

The results are shown in the Tables 1-3 and Figure 1(1-12).

\section{Traditional use}

The plants selected for the phytochemical analysis are used by the practitioners of traditional medicine and their various uses are listed in Table 1.

\begin{tabular}{|c|c|c|c|c|c|}
\hline S. No. & Scientific Name & Local Name & Family & Traditional use & Reference \\
\hline 1 & Alocasia indica & Saidawl/ Vandawl & Araceae & $\begin{array}{l}\text { Jaundice, rheumatic arthritis, antifungal } \\
\begin{array}{l}\text { anti-inflammatory, anti-leprotic, } \\
\text { anasarca, abdomen and spleen. } \\
\text { diseases }\end{array}\end{array}$ & Nadkarni [51], Sawmliana [43] \\
\hline 2 & Bidens pillosa & Vawk-pui-thal & Compositae & $\begin{array}{l}\text { Anti-inflammatory, anti-malarial, anti- } \\
\text { influenza, anti-diabetic, } \\
\text { gastroenteritis, anti- } \\
\text { antitumor. }\end{array}$ & $\begin{array}{l}\text { Geissberger and Sequin [46], Jager et } \\
\text { al. [47], Andrade-Neto et al. [49], } \\
\text { Steenkamp and Gouws [50] }\end{array}$ \\
\hline 3 & Blumeopsis flava & Khawn-var-tui-rim-nam & Compositae & $\begin{array}{l}\text { Dropsy. Leaf decoction: bronchial } \\
\text { congestion, cold, cough, skin diseases } \\
\text { and backache. }\end{array}$ & $\begin{array}{l}\text { Anonymous [52], } \\
\text { Singh et al. [62] }\end{array}$ \\
\hline 4 & Carica papaya & $\begin{array}{l}\text { Thing-fang-hma/Nu- } \\
\text { hnun }\end{array}$ & Caricaceae & $\begin{array}{l}\text { Treatment for jaundice, diabetes, food } \\
\text { poisoning and dog bites }\end{array}$ & Sawmliana [43] \\
\hline 5 & $\begin{array}{l}\text { Chromolaena odo } \\
\text { rata }\end{array}$ & Tlang-sam/ Pho-leng & Compositae & $\begin{array}{l}\text { Anti- diarrheal, astringent, } \\
\text { antispasmodic, antihypertensive, anti- } \\
\text { inflammatory and diuretic and wound } \\
\text { healing. }\end{array}$ & $\begin{array}{l}\text { Iwu et al. [42], } \\
\text { Sawmliana [43] }\end{array}$ \\
\hline 6 & Cissus discolor & Sa-nghar-hmai & Vitaceae & Stomach troubles, and itching sores. & Sawmliana [43] \\
\hline 7 & Croton caudatus & $\begin{array}{l}\text { Ran-lung dam-dawi/ } \\
\text { Kam-sa-hulh (Ratu) }\end{array}$ & Euphorbiaceae & $\begin{array}{l}\text { Given to women after delivery of baby. } \\
\text { Kills the sore-worms in pigs and cattles. }\end{array}$ & Sawmliana [43] \\
\hline 8 & Cucurma caesia & Ai-lai-dum & Zingiberaceae & $\begin{array}{l}\text { Indicated in stomach-ache, dysentery, } \\
\text { jaundice, asthma, measles and food } \\
\text { allergy or food poisoning. }\end{array}$ & Sawmliana [43] \\
\hline 9 & $\begin{array}{l}\text { Elaeagnus } \\
\text { caudata }\end{array}$ & Sar-zuk-pui & Elaeagnaceae & $\begin{array}{l}\text { Root decoction is used for expelling } \\
\text { placenta, also to stop the menses and } \\
\text { as Health tonic. }\end{array}$ & Sawmliana [43] \\
\hline 10 & $\begin{array}{l}\text { Leucaena leucoc } \\
\text { ephala }\end{array}$ & $\begin{array}{l}\text { Japan-Zawng-tah/Kawl- } \\
\text { zawng-tah }\end{array}$ & Mimosaceae & Constipation, dysentery and ascariasis. & $\begin{array}{l}\text { Singh et al. [62], } \\
\text { Prajapati et al. [57] }\end{array}$ \\
\hline 11 & Passiflora edulis & Sap-thei & Passifloraceae & $\begin{array}{l}\text { Jaundice, and anxiety. Sedative and } \\
\text { tranquillizer. }\end{array}$ & Sawmliana [43], \\
\hline 12 & $\begin{array}{l}\text { Spilanthes } \\
\text { acmella }\end{array}$ & An-sa-pui/Aa-ka-sa-kir & Compositae & $\begin{array}{l}\text { Headaches, paralysis of the tongue, } \\
\text { throat, and gums infections, } \\
\text { stammering, anti-inflammatory and } \\
\text { analgesic. }\end{array}$ & $\begin{array}{l}\text { Sawmliana [43], Chakraborty et al. } \\
\text { [55] }\end{array}$ \\
\hline
\end{tabular}

Table 1: Traditional uses of the some medicinal plants. 
Page 4 of 9

Alocasia indica belongs to family Araceae and is locally known as saidawl or vandawl, its roots are edible and it is used to cure inflammation, leprosy, anasarca, diseases of the abdomen and spleen. It is an antifungal agent and is also given to treat jaundice, and rheumatic arthritis (Table 1).

Bidens pillosa (family Compositae) or Vawk-pui-thal is used to treat inflammatory diseases, malaria, influenza, diabetes, gastroenteritis, and cancer or tumor growth (Table 1).

Blumeopsis flava or Khawn-var-tui-rim-nam belongs to family Compositae. Its leaves are mixed with mustard oil and applied in dropsy. The leaf decoction is useful in bronchial congestion, cold, cough and skin diseases. The hot fomented plant is applied as a bandage to relieve backache (Table 1).

Carica papaya belongs to family Caricaceae and is locally known as Thing-fang-hma/Nu-hnun. Its latex is used in the treatment of jaundice, diabetes, food poisoning and dog bites (Table 1).

Chromolaena odorata is locally known as Tlang-sam/Pho-leng and belongs to family Compositae. It is used in treating diarrhea, spasmodic pain, blood pressure and wounds (Table 1). It also acts as astringent and diuretic.

Cissus discolor (family Vitaceae) Sa-nghar-hmai (local name) is used to treat stomach troubles and is also applied to itching sores (Table 1).

Croton caudatus Giesler is locally known as Ran-lung dam-dawi/ Kam-sa-hulh (Ratu) and belongs to family Euphorbiaceae. Its root or leaf decoction is given to women after delivery of a baby. The leaves are used to kill the sore-worms for pigs and cattles (Table 1).

Cucurma caesia Roxb. is locally known as Ai-lai-dum and it belongs to family Zingiberacae. It has been used in stomachache, dysentery, jaundice, asthma, measles and food allergy or food poisoning by the practitioner of folklore medicine (Table 1).
Elaeagnus caudata (family Elaeagnaceae) is locally known as Sarzuk-pui and its strong bark decoction is mixed with oil and used as an ointment to treat frostbite. A decoction of the roots is combined with sumac roots to treat syphilis. Its root infusion is taken orally to expel placenta. The juice of crushed root of Elaeagnus caudata is also given for easy labour. The infusion of leaves is taken orally for strengthening the functions of uterus. It is also given as tea after childbirth (Table 1).

Leucaena leucocephala is also known locally as Japan-Zawng-tah/ Kawl-zawng-tah and it belongs to family Mimosaceae. The leaf decoction is mixed with little amount of common salt to relieve constipation and tender pods are eaten in dysentery. Its seeds have a beneficial effect in ascariasis (Table 1).

Passiflora edulis is the member of family Passifloraceae and its local name is Sap-thei. It is generally used to treat jaundice and liver problems. Its fruits are useful in anxiety. It acts as a sedative and tranquillizer (Table 1).

Spilanthes acmella is locally called as An-sa-pui/Aa-ka-sa-kir and belongs to family Compositae. It is used in the treatment of headaches, tongue paralysis, infections of the throat, gums and toothache. It is anti-inflammatory and analgesic and a very popular remedy to treat stammering in children (Table 1).

\section{Phytochemical analysis}

The phytochemical analysis of selected plant showed the presence of alkaloids, flavonoids, saponins, and steroids in all the specimens (Table 2). They also contained tannins (except Croton caudatus) phlobatannins (except Spilanthes acmella and Passiflora edulis), cardiac glycoside (except Alocasia indica and Elaeagnus caudata) and terpenoids (except Leucaena leucocephala and Elaeagnus caudata) (Table 2).

\begin{tabular}{|c|c|c|c|c|c|c|c|c|c|}
\hline \multirow{2}{*}{$\begin{array}{l}\text { S. } \\
\text { No. }\end{array}$} & \multirow[t]{2}{*}{ Plant name } & \multicolumn{8}{|c|}{ Phytoconstituents } \\
\hline & & Alkaloids & Tannins & Saponins & Steroids & $\begin{array}{l}\text { Phloba- } \\
\text { tannins }\end{array}$ & Terpenoids & Flavonoids & $\begin{array}{l}\text { Cardic } \\
\text { Glycosides }\end{array}$ \\
\hline 1 & Alocasia indica & + & + & + & + & + & + & + & - \\
\hline 2 & Bidens pillosa & + & + & + & + & + & + & + & + \\
\hline 3 & Blumeopsis flava & + & + & + & + & + & + & + & + \\
\hline 4 & Carica papaya & + & - & + & + & - & + & + & + \\
\hline 5 & Chromolaena odorata & + & + & + & + & + & + & + & + \\
\hline 6 & Cissus discolor & + & + & + & + & + & + & + & + \\
\hline 7 & Croton caudatus & + & - & + & + & + & + & + & + \\
\hline 8 & Cucurma caesia & + & - & + & + & - & + & + & + \\
\hline 9 & Elaeagnus caudata & + & + & + & + & - & - & + & - \\
\hline 10 & Leucaena leucocephala & + & + & + & + & - & - & + & + \\
\hline 11 & Passiflora edulis & + & + & + & + & - & + & + & + \\
\hline
\end{tabular}


Citation: Shantabi L, Jagetia GC, Vabeiryureilai M, Lalrinzuali K (2014) Phytochemical Screening of Certain Medicinal Plants of Mizoram, India and their Folklore Use. J Biodivers Biopros Dev 1: 136. doi:10.4172/2376-0214.1000136

Page 5 of 9

\begin{tabular}{|l|l|l|l|l|l|l|l|l|l|}
\hline 12 & Spilanthes acmella & + & + & + & + & - & + & & + \\
\hline
\end{tabular}

Table 2: The Phytochemical analysis of the various medicinal plants. $+=$ Presence - = absence.

TLC

The evaluations of various plants extract showed presence of different components as indicated by varying number of spots on a
TLC plate and different Rf values (Table 3). The TLC profiles are depicted in Figure 1 (1-12).

\begin{tabular}{|c|c|c|c|c|c|}
\hline S. No. & $\begin{array}{l}\text { Plant Name and Extract } \\
\text { used. }\end{array}$ & Part used & Solvent used and visualization & Rf value & Colour of the band \\
\hline 1 & $\begin{array}{l}\text { Alocasia indica } \\
\text { Chloroform extract }\end{array}$ & Stock & $\begin{array}{l}\text { Benzene / acetone(9.5:0.5) } \\
\text { Colour in UV }\end{array}$ & 0.62 & Blue fluorescent \\
\hline 2 & $\begin{array}{l}\text { Bidens pillosa } \\
\text { Chloroform extract }\end{array}$ & Leaves & $\begin{array}{l}\text { nhexane/ethylacetate }(7: 3) \\
\text { Colour in daylight }\end{array}$ & $\begin{array}{l}0.2 \\
0.34 \\
0.51 \\
0.6 \\
0.71 \\
0.88\end{array}$ & $\begin{array}{l}\text { Light yellow } \\
\text { Light green } \\
\text { Light grey } \\
\text { Greenish yellow } \\
\text { Dark grey } \\
\text { Yellow }\end{array}$ \\
\hline 3 & $\begin{array}{l}\text { Blumeopsis flava } \\
\text { Chloroform extract }\end{array}$ & Leaves & $\begin{array}{l}\text { nhexane/ethylacetate }(7: 3) \\
\text { Colour in daylight }\end{array}$ & $\begin{array}{l}0.21 \\
0.35 \\
0.48 \\
0.62\end{array}$ & $\begin{array}{l}\text { Light yellow } \\
\text { Light yellow } \\
\text { Deep yellow } \\
\text { Deep green }\end{array}$ \\
\hline 4 & $\begin{array}{l}\text { Carica papaya } \\
\text { Chloroform extract }\end{array}$ & Latex & $\begin{array}{l}\text { Benzene/acetone }(7: 3) \\
\text { Visible after spraying Anisaldehyde reagent and } \\
\text { kept in the oven at } 120^{\circ} \mathrm{C} \text { for } 20 \text { mins. } \\
\text { Chloroform/methanol }(3: 2) \\
\text { Visible after spraying with Dragendroff's reagent }\end{array}$ & $\begin{array}{l}0.27 \\
0.40 \\
0.56 \\
0.64 \\
0.8\end{array}$ & $\begin{array}{l}\text { Light violet } \\
\text { Light grey } \\
\text { Deep violet } \\
\text { Light grey } \\
\text { Deep orange }\end{array}$ \\
\hline 5 & $\begin{array}{l}\text { Chromolaena odorata } \\
\text { Chloroform extract }\end{array}$ & Leaves & $\begin{array}{l}\text { nhexane/ethylacetate }(7: 3) \\
\text { Colour in daylight } \\
\text { Visible after spraying with Dragendroff's reagent }\end{array}$ & $\begin{array}{l}0.13 \\
0.35 \\
0.54 \\
0.62 \\
0.94 \\
0.35\end{array}$ & $\begin{array}{l}\text { Deep yellow } \\
\text { Yellowish green } \\
\text { Light grey } \\
\text { Dark grey } \\
\text { Light yellow } \\
\text { Deep orange }\end{array}$ \\
\hline 6 & $\begin{array}{l}\text { Cissus discolor } \\
\text { Chloroform extract }\end{array}$ & Leaves & $\begin{array}{l}\text { nhexane/ethylacetate }(7: 3) \\
\text { Colour in daylight }\end{array}$ & $\begin{array}{l}0.42 \\
0.51 \\
0.57 \\
0.68 \\
0.88\end{array}$ & $\begin{array}{l}\text { Light yellowish } \\
\text { Deep yellow } \\
\text { Light green } \\
\text { Deep green } \\
\text { Light green }\end{array}$ \\
\hline 7 & $\begin{array}{l}\text { Croton caudatus } \\
\text { Chloroform extract }\end{array}$ & Leaves & $\begin{array}{l}\text { Benzene/acetone (9.5:0.5) } \\
\text { Colour in UV }\end{array}$ & $\begin{array}{l}0.14 \\
0.57 \\
0.68\end{array}$ & $\begin{array}{l}\text { Bluish green } \\
\text { Fluorescent green } \\
\text { Blue }\end{array}$ \\
\hline 8 & $\begin{array}{l}\text { Cucurma caesia } \\
\text { Chloroform extract }\end{array}$ & Rhizomes & $\begin{array}{l}\text { Dichloromethane/ methanol (9:1) } \\
\text { Colour in daylight } \\
\text { Dichloromethane/ methanol (8:2) } \\
\text { Spray with Dragendroff's reagent } \\
\text { Benzene/acetone (9.5:0.5) } \\
\text { Colour in UV }\end{array}$ & $\begin{array}{l}0.70 \\
0.94 \\
0.18 \\
0.27 \\
0.64 \\
0.94\end{array}$ & $\begin{array}{l}\text { Brownish } \\
\text { Deep orange } \\
\text { Bluish } \\
\text { Light green } \\
\text { Fluorescent } \\
\text { Blue }\end{array}$ \\
\hline
\end{tabular}


Citation: Shantabi L, Jagetia GC, Vabeiryureilai M, Lalrinzuali K (2014) Phytochemical Screening of Certain Medicinal Plants of Mizoram, India and their Folklore Use. J Biodivers Biopros Dev 1: 136. doi:10.4172/2376-0214.1000136

Page 6 of 9

\begin{tabular}{|c|c|c|c|c|c|}
\hline 9 & $\begin{array}{l}\text { Elaeagnus caudata } \\
\text { Chloroform extract }\end{array}$ & Leaves & $\begin{array}{l}\text { nhexane/ethylacetate }(7: 3) \\
\text { Colour in daylight }\end{array}$ & $\begin{array}{l}0.6 \\
0.8 \\
1.1 \\
1.5 \\
1.9 \\
2.2 \\
3.2\end{array}$ & $\begin{array}{l}\text { Deep yellow } \\
\text { Yellowish green } \\
\text { Light grey } \\
\text { Light yellow } \\
\text { Light green } \\
\text { Deep green } \\
\text { Light yellow }\end{array}$ \\
\hline 10 & $\begin{array}{l}\text { Leucaena leucocephala } \\
\text { Synonym Leucaena glauca } \\
\text { Chloroform extract }\end{array}$ & Leaves & $\begin{array}{l}\text { nhexane/ethylacetate }(7: 3) \\
\text { Colour in daylight }\end{array}$ & $\begin{array}{l}0.41 \\
0.5 \\
0.58 \\
0.66\end{array}$ & $\begin{array}{l}\text { Light yellow } \\
\text { Deep yellow } \\
\text { Light grey } \\
\text { Deep grey }\end{array}$ \\
\hline 11 & $\begin{array}{l}\text { Passiflora edulis } \\
\text { Chloroform extract }\end{array}$ & Leaves & $\begin{array}{l}\text { nhexane/ethylacetate }(7: 3) \\
\text { Colour in daylight }\end{array}$ & $\begin{array}{l}0.17 \\
0.41 \\
0.48 \\
0.53 \\
0.58 \\
0.66 \\
0.71 \\
0.94\end{array}$ & $\begin{array}{l}\text { Deep yellow } \\
\text { Light green } \\
\text { Yellowish green } \\
\text { Light green } \\
\text { Light grey } \\
\text { Deep grey } \\
\text { Light grey } \\
\text { Light yellow }\end{array}$ \\
\hline 12 & $\begin{array}{l}\text { Spilanthes acmella } \\
\text { Chloroform extract }\end{array}$ & Leaves & $\begin{array}{l}\text { nhexane/ethylacetate }(7: 3) \\
\text { Colour in daylight }\end{array}$ & $\begin{array}{l}0.18 \\
0.29 \\
0.43 \\
0.48 \\
0.62\end{array}$ & $\begin{array}{l}\text { Light yellow } \\
\text { Light grey } \\
\text { Deep yellow } \\
\text { Light green } \\
\text { Dark green }\end{array}$ \\
\hline
\end{tabular}

Table 3: Rf values of different extracts of the different plants in various solvent systems.

\section{Discussion}

The plants synthesize several chemicals for various purposes and these chemicals have medicinal and healing effects in humans. Analysis of chemical components of plants is useful in new drug development and also synthesis of some complex chemicals for medical use. The plants usually contain several chemical components including alkaloids, tannins, flavonoids, phenolics and other secondary metabolites, which have been reported to elicit physiological and biochemical response in the human body [17]. Alkaloid-containing plants have been used by humans since ancient times for therapeutic and recreational purposes. The cocaine and morphine alkaloids are used as local anesthetic and are also used as stimulants. Similarly, caffeine, nicotine, and quinine (an antimalarial drug) act as stimulants. Several alkaloids including vinca alkaloids and taxol isolated from plants have been found to be potent anticancer agents $[18,19]$. Saponins have been reported to possess a wide range of biological activities including antibacterial activity [20-22].

Several reports have shown that flavonoids act as good antioxidants in vitro and in vivo [23-25]. Flavonoids play different roles in the ecology of plants. Because of their astringency, catechins and other flavonoids help to protect plants against harmful insects as well as stress $[25,26]$. The antioxidant abilities of flavonoids in vitro may be stronger than those of vitamin $\mathrm{C}$ and $\mathrm{E}$, depending on the concentrations used [27]. Various studies in vitro and in vivo showed that flavonoids possess antimicrobial, anti-cancer, anti-diarrheal and radioprotective activities [22,23,28-32]. In vitro studies have shown that flavonoids act on enzyme systems critically involved in the initiation and maintenance of inflammatory response. Flavonoids inhibit the acetyltransferase (AT) $[33,34]$ and phospholipase A2(PL2) activities [35] and they also inhibit platelet function[36] and endothelial cell adhesion protein gene expression [37]. Flavonoids have been also reported to protect against the development of atherosclerosis [38,39].

Steroids have been found in all the plants. Steroidal compounds are of importance and interest in pharmacy due to their close relationship with hormones including sex hormones [40]. Steroids have been used as anti-inflammatory and analgesic agents in modern clinical situation to treat patients [41]. All the plant specimens under investigation were found to contain alkaloids, flavonoids, saponin, and steroids. The wound healing, antidiarrheal, astringent, antispasmodic, antihypertensive, anti-inflammatory and diuretic activities of Chromolaena odorata leaves may be due to the presence of alkaloids, flavonoids, saponins and steroids [42,43]. Croton caudatus has been used for the treatment of malaria, ardent fever, convulsions, rheumatic arthritis, and numbness [44]. 
Citation: Shantabi L, Jagetia GC, Vabeiryureilai M, Lalrinzuali K (2014) Phytochemical Screening of Certain Medicinal Plants of Mizoram, India and their Folklore Use. J Biodivers Biopros Dev 1: 136. doi:10.4172/2376-0214.1000136

Page 7 of 9

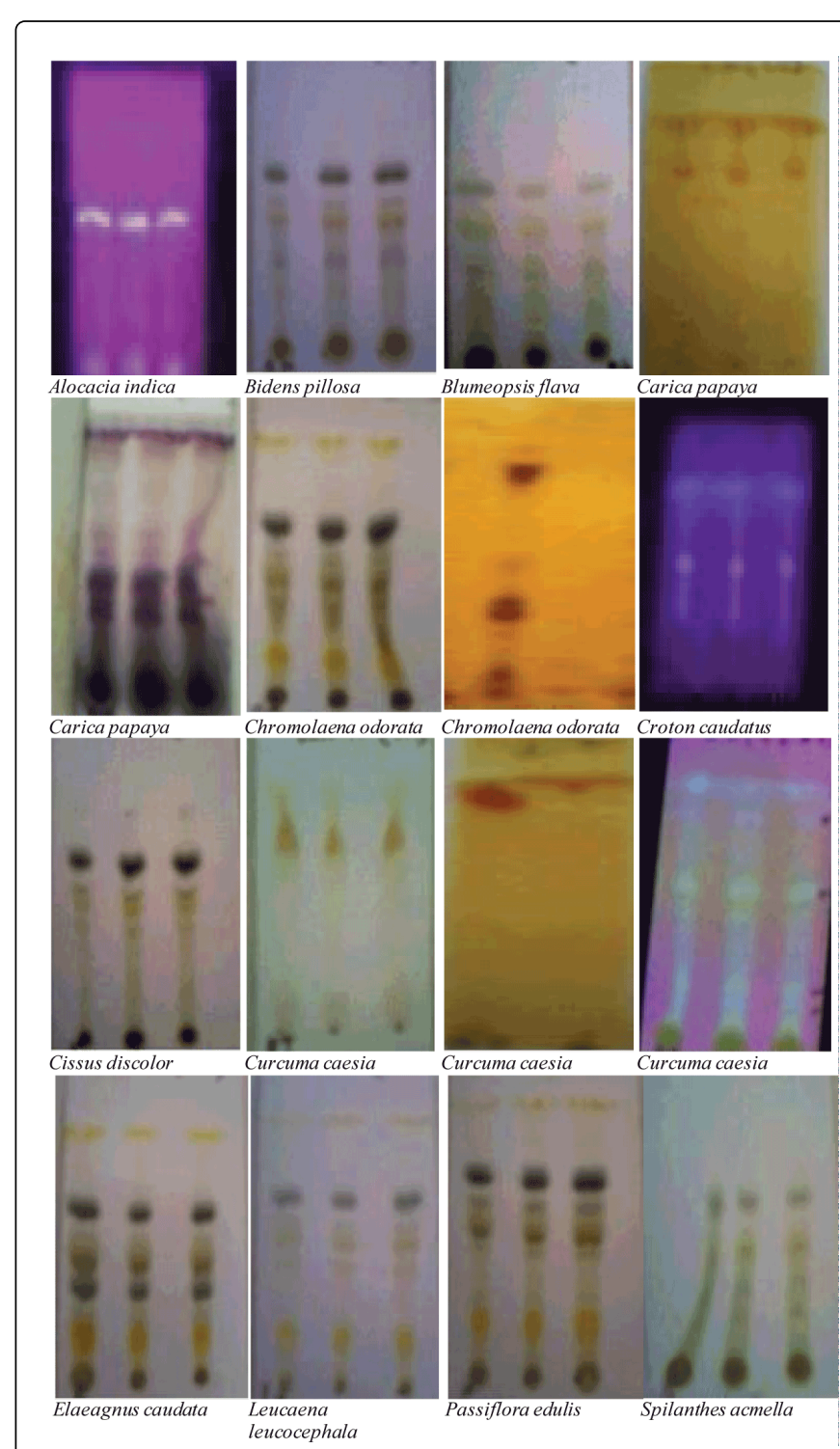

Figure 1: TLC profiles of various plants.

The leaves are also used to kill the sore-worms for pigs and cattles [43]. Further investigations on the chemical constituents of this species have now led to the isolation of a new flavone 1, along with nine known ones [45], which once again proves its utility in traditional medicine. We have isolated $\beta$ and stigma sterols from Croton caudatus recently (unpublished data). The leaves of Bidens pillosa are used in folklore medicine against inflammation, malaria, cancer and other tumors. The presence of alkaloids supports its use as an anticancer therapeutic agent [46-50].

The leaves of Spilanthes acmella have been reported as diuretic, anti-inflammatory, analgesic, vasorelaxant, antioxidant, antibacterial, tonic and digestive [51-56]. It is also used to treat headaches, paralysis of the tongue, infections of the throat, gums and toothache [43]. All these activities may be due to the presence of various phytochemicals, which have been identified in it. Traditionally, Alocasia indica has been used to cure inflammation, leprosy, anasarca, diseases of the abdomen and spleen [43]. It has been found to contain flavonoids, cynogenetic glycosides, alocasin, amino acids, succinic acid and $\beta$ lectin [57]. Flavonoids have been shown to possess various biological properties related to antioxidant mechanism [25,58]. Thus, the antioxidant potential of $A$. indica may be attributed to the presence of flavonoids and other phytochemicals in it. Papaya juice has been shown to possess an in vitro antiproliferative effect on liver cancer cells, possibly due to the presence of lycopene or immune stimulation [59]. Papaya seeds have been reported to possess antibacterial properties against Escherichia coli, Staphylococcus aureus or Salmonella typhi and anthelmintic [60,61].

Leucaena leucocephala has been employed in traditional medicine for the treatment of dysentery and the leaves of Cissus discolor have been used as a remedy in stomach troubles and itching sores [62]. These activities may due to the presence of tannins and other phytochemicals. Tannins have been reported to prevent urinary tract infection and intestinal disorders like dysentery and diarrhea [63]. Tannins have also shown potential to exert antiviral, antibacterial and antiparasitic effects earlier [64-66].

TLC profiling and phytochemical analysis have revealed the presence of various phytochemicals including alkaloids, steroids, flavonoids, terpenoids, tannins, phlobatannins, saponins and cardiac glycosides in various plants investigated in this study. These plants have been employed by the traditional healers for the treatment of various health disorders. The disease curing effects of these plants may be due to concerted action of alkaloids, steroids, flavonoids, terpenoids, tannins, phlobatannins, saponins and cardiac glycosides singly or in combination. Alkaloids, steroids, flavonoids, terpenoids, tannins, phlobatannins, saponins and cardiac glycosides have been already known to possess different activities. The phytochemical analysis of these plants indicates that the traditional healers though may be ignorant about their phytochemical constituents, certainly knew their beneficial effects in the human healthcare.

\section{Acknowledgement}

The financial support from Non-SAP UGC Meritorious fellowship to Longjam Shantabi to carry out the above work is gratefully acknowledged.

\section{References}

1. Dash B, Sharma BK (2001) Charak Samhita. Chaukhamba Sanskrit Series Office, Varanasi, India 7th Edition.

2. Kong JM, Goh NK, Chia LS, Chia TF (2003) Recent advances in traditional plant drugs and orchids. Acta Pharmacol Sin 24: 7-21.

3. Jagetia GC, Venkatesha VA (2005) Effect of mangiferin on radiationinduced micronucleus formation in cultured human peripheral blood lymphocytes. Environ Mol Mutagen 46: 12-21.

4. Cordell GA (2011) Sustainable medicines and global health care. Planta Med 77: 1129-1138.

5. Patwardhan B, Warude D, Pushpangadan P, Bhatt N (2005) Ayurveda and traditional Chinese medicine: a comparative overview. Evid Based Complement Alternat Med 2: 465-473.

6. Gupta R, Chadha KL (1995) Medicinal and Aromatic Plants in India. Advances in Horticulture, Medicinal and Aromatic Plants. Malhotra Publishing House, New Delhi: 1-14.

7. Singh HB (2000) Alternative Source for some Conventional Drug Plants of India. Ethnobotany and medicinal plants of Indian Subcontinent. (ed Maheshwari JK). Scientific Publishers, Jodhpur, India: 63-78.

8. Rao RR (1996) Traditional knowledge and sustainable development, Key role of Ethnobiologist. Journal of Ethnobotany 8: 14-24 
9. Anonymous (2009) Mosby's Medical Dictionary, 8th edition, Elsevier.

10. Duraipandiyan V, Ayyanar M, Ignacimuthu S (2006) Antimicrobial activity of some ethnomedicinal plants used by Paliyar tribe from Tamil Nadu, India. BMC Complement Altern Med 6: 35.

11. Cragg GM, Newman DJ (2013) Natural products: a continuing source of novel drug leads. Biochim Biophys Acta 1830: 3670-3695.

12. Rai PK, Lalramnghinglova $\mathrm{H}$ (2010) Ethnomedicinal plant resources of Mizoram, India: Implication of traditional knowledge in healthcare system. Ethnobotanical Leaflets 14: 274-305.

13. Harborne JB (1998) Phytochemical Methods A Guide to Modern Techniques of Plant Analysis. London. Chapman and Hall, Ltd: 1-129.

14. Doughari JH (2012) Phytochemicals: extraction methods, basic structures and mode of action as potential chemotherapeutic agents, phytochemicals - A global perspective of their role in nutrition and health. Dr. Venketeshwer Rao (Ed.), InTech, Rijeka, Croatia.

15. Trease GE, Evans WC (1989) Pharmacognsy. 11thed Brailliar Tiridel Can. McMillian publishers.

16. Sofowara A (1993) Medicinal plants and Traditional medicine in Africa. Spectrum Books Ltd, Ibadan, Nigeria: 289.

17. Hill AF (1952) Economic Botany. A textbook of useful plants and plant products. 2ndedn. McGraw-Hill Book Company Inc, New York.

18. Nicolaou KC, Yang Z, Liu JJ, Ueno H, Nantermet PG, et al. (1994) Total synthesis of taxol. Nature 367: 630-634.

19. Moudi M, Go R2, Yien CY1, Nazre M3 (2013) Vinca alkaloids. Int J Prev Med 4: 1231-1235.

20. Marston A, Gafner F, Dossagi SF, Hostettmann K (1988) Fungicidal and molluscicidal saponins from Dolichos kilimandscharicus. Phytochemistry 27: 1325- 1326.

21. Ohtani K, Mavi S, Hostettmann K (1993) Molluscicidal and antifungal triterpenoid saponins from Rapanea melanophloeos. Phytochemistry 33: 83-86.

22. Nagata T, Tsushida T, Hamaya E, Enoki N, Manabe S, et al. (1985) Camellidins, antifungal saponins isolated from Camellia japonica. Agricultural Biological Chemistry 49: 1181.

23. Jagetia GC, Venkatesha VA, Reddy TK (2003) Naringin, a citrus flavonone, protects against radiation-induced chromosome damage in mouse bone marrow. Mutagenesis 18: 337-343.

24. Jagetia GC, Reddy TK (2005) Modulation of radiation-induced alteration in the antioxidant status of mice by naringin. Life Sci 77: 780-794.

25. Agati G, Azzarello E, Pollastri S, Tattini M (2012) Flavonoids as antioxidants in plants: location and functional significance. Plant Sci 196: 67-76.

26. Mazza G, Miniati E (1993) Anthocyanins in Fruits, Vegetables and Grains; CRC Press: Boca Raton, FL, USA.

27. Bagchi M, Milnes M, Williams C, Balmoori J, Ye X, et al. (1999) Acute and chronic stress-induced oxidative gastrointestinal injury in rats, and the protective ability of a novel grape seed proanthocyanidin extract Nutrition Research19: 1189-1199.

28. Cushnie TP, Lamb AJ (2005) Antimicrobial activity of flavonoids. Int Antimicrob Agents 26: 343-356.

29. Schuier M, Sies H, Illek B, Fischer H (2005) Cocoa-related flavonoids inhibit CFTR-mediated chloride transport across T84 human colon epithelia. J Nutr 135: 2320-2325.

30. Jagetia GC, Reddy TK (2002) The grapefruit flavanone naringin protects against the radiation-induced genomic instability in the mice bone marrow: a micronucleus study. Mutat Res 519: 37-48.

31. De Sousa R, Queiroz KC, Souza AC, Gurgueira SA, Augusto AC, et al. (2007) Phosphoprotein levels, MAPK activities and NF-?B expression are affected by fisetin. Journal of Enzyme Inhibition and Medicinal Chemistry 22: 439-444.

32. Cushnie TP, Lamb AJ (2011) Recent advances in understanding the antibacterial properties of flavonoids. Int J Antimicrob Agents 38: 99-107.
33. Yanoshita R, Chang HW, Son KH, Kudo I, Samejima Y (1996) Inhibition of lysoPAF acetyltransferase activity by flavonoids. Inflamm Res 45: 546-549.

34. Manthey JA, Grohmann K, Guthrie N (2001) Biological properties of citrus flavonoids pertaining to cancer and inflammation. Curr Med Chem 8: 135-153.

35. Lindahl M, Tagesson C (1997) Flavonoids as phospholipase A2 inhibitors: importance of their structure for selective inhibition of group II phospholipase A2. Inflammation 21: 347-356.

36. Freedman JE, Parker C 3rd, Li L, Perlman JA, Frei B, et al. (2001) Select flavonoids and whole juice from purple grapes inhibit platelet function and enhance nitric oxide release. Circulation 103: 2792-2798.

37. Gerritsen ME, Carley WW, Ranges GE, Shen CP, Phan SA, et al. (1995) Flavonoids inhibit cytokine-induced endothelial cell adhesion protein gene expression. Am J Pathol 147: 278-292.

38. Koga T, Meydani M (2001) Effect of plasma metabolites of (+)-catechin and quercetin on monocyte adhesion to human aortic endothelial cells. Am J Clin Nutr 73: 941-948.

39. Grassi D, Desideri G, Ferri C (2010) Flavonoids: antioxidants against atherosclerosis. Nutrients 2: 889-902.

40. Okwu DE (2001) Evaluation of the chemical composition of indigenous spices and flavouring agents. Global Journal of Pure and Applied Science $7(3): 455-459$.

41. Singh AP (2006) Short Review Distribution of Steroid like Compounds in Plant Flora. Pharmacognosy Magazine 2: 87-89.

42. Iwu MM, Duncan AR, Okunji CO (1999) New antimicrobials of plant origin. Perspectives on new crops and new uses. ASHS Press, Alexandria, VA: $457-462$.

43. Sawmliana M (2003) The Book of Mizoram plants First ed. Lois Bet, Chandmari, Aizawl.

44. Jiangsu New Medical College (1975) Dictionary of Traditional Chinese Medicine; Shanghai Science and Technology Press: Shanghai, China: 447.

45. Zou GA, Su ZH, Zhang HW, Wang Y, Yang JS, et al. (2010) Flavonoids from the stems of Croton caudatus Geisel. var. tomentosus Hook. Molecules 15: 1097-1102.

46. Geissberger P, Séquin U (1991) Constituents of Bidens pilosa L.: do the components found so far explain the use of this plant in traditional medicine? Acta Trop 48: 251-261.

47. Jäger AK, Hutchings A, van Staden J (1996) Screening of Zulu medicinal plants for prostaglandin-synthesis inhibitors. J Ethnopharmacol 52: 95-100.

48. Brandão MG, Krettli AU, Soares LS, Nery CG, Marinuzzi HC (1997) Antimalarial activity of extracts and fractions from Bidens pilosa and other Bidens species (Asteraceae) correlated with the presence of acetylene and flavonoid compounds. Journal of Ethnopharmacology 57: 131-138.

49. Andrade-Neto VF, Brandão MG, Oliveira FQ, Casali VW, Njaine B, et al. (2004) Antimalarial activity of Bidens pilosa L. (Asteraceae) ethanol extracts from wild plants collected in various localities or plants cultivated in humus soil. Phytother Res 18: 634-639.

50. Steenkamp V, Gouws MC (2006) Cytotoxicity of six South African plants extracts used in the treatment of cancer. South African Journal of Botany 72: 630-633.

51. Nadkari AK (1976) Indian Material Media, Bombay: Popular Prakashan Pvt. Ltd.

52. Anonymous (1988) The Wealth of India, A dictionary of Indian raw materials and industrial products. CSIR, New Delhi: Publication and Information Directorate, New Delhi.

53. Rastogi BN (1993) Compendium of Indian Medicinal Plants Vol. II, CDRI Lucknow: Publication and Information Directorate, New Delhi.

54. Ratnasooriya WD, Pieris KP, Samaratunga U, Jayakody JR (2004) Diuretic activity of Spilanthes acmella flowers in rats. J Ethnopharmacol 91: 317-320.

55. Chakraborty A, Devi RKB, Rita S, Sharatchandra Kh, Singh I Th (2004) Preliminary studies on anti-inflammatory and analgesic activities of 
Citation: Shantabi L, Jagetia GC, Vabeiryureilai M, Lalrinzuali K (2014) Phytochemical Screening of Certain Medicinal Plants of Mizoram, India and their Folklore Use. J Biodivers Biopros Dev 1: 136. doi:10.4172/2376-0214.1000136

Page 9 of 9

Spilanthes acmella in experimental animal models. Indian Journal of Pharmacology 36: 148-150.

56. Wongsawatkul O, Prachayasittikul S, Isarankura-Na-Ayudhya C, Satayavivad J, Ruchirawat S, et al. (2008) Vasorelaxant and antioxidant activities of Spilanthes acmella Murr. Int J Mol Sci 9: 2724-2744.

57. Prajapati ND, Purohit SS, Sharma AK, Kumar T (2003) A Handbook of Medicinal Plants. A Complete Source Book. Agrobios India, Jodhpur, first edition.

58. World Health Organization (1998) Quality control methods for medicinal plants materials. Geneva: 32 .

59. Giordani R, Siepaio M, Moulin-Traffort J, Régli P (1991) Antifungal action of Carica papaya latex: isolation of fungal cell wall hydrolysing enzymes. Mycoses 34: 469-477.

60. Le Grand A (1989) [Anti-infective phytotherapies of the tree-savannah, Senegal (occidental Africa). III: A review of phytochemical substances and the antimicrobial activity of 43 species]. J Ethnopharmacol 25: 315-338.
61. Satrija F, Nansen P, Bjørn H, Murtini S, He S (1994) Effect of papaya latex against Ascaris suum in naturally infected pigs. J Helminthol 68 343-346.

62. Singh HB, Singh RS, Sandhu JS (2003) Herbal Medicine of Manipur. Colour Encyclopaedia. Daya Publishing House, New Delhi: 9-24.

63. Okwu DE, Josiah C (2006) Evaluation of the chemical composition of two Nigerian medicinal plants. African Journal of Biotechnology 5 : 357-361.

64. Lü L, Liu SW, Jiang SB, Wu SG (2004) Tannin inhibits HIV-1 entry by targeting gp41. Acta Pharmacol Sin 25: 213-218.

65. Akiyama H, Fujii K, Yamasaki O, Oono T, Iwatsuki K (2001) Antibacterial action of several tannins against Staphylococcus aureus. J Antimicrob Chemother 48: 487-491.

66. Kolodziej H, Kiderlen AF (2005) Antileishmanial activity and immune modulatory effects of tannins and related compounds on Leishmania parasitised RAW 264.7 cells. Phytochemistry 66: 2056-2071. 